\title{
Pile group settlement analysis on the basis of Static Load Test
}

\author{
Nikola Dudek* \\ Wroclaw University of Science and Technology, Wyb. Wyspiańskiego 27, 50-370 \\ Wrocław, Poland
}

\begin{abstract}
Settlement of large pile groups is most often estimated by the Alternative Foundation Method. However, this method has some limitations related to assumed uniformity of pile loads. A very big problem is also related to estimating the stiffness of subgrade loaded by a group of piles. Similar problems arise when piled foundation is numerically modelled in Finite Element Method or Boundary Element Method programmes. The results obtained are highly dependent on the input data, especially on characteristics describing soil subgrade stiffness and strength and moduli at pile - soil contact. The paper presents an example of using the results of trial static calculations for the pile made using a technology not identical with that ultimately implemented for the project. The subgrade stiffness modulus was determined with Inverse Analysis using bored pile test load. The results attained were used for further calculations (forecast) the settlement of prefabricated driven pile (a single one) and then to estimate of pile group settlement under full load from bridge structure abutment.
\end{abstract}

\section{Introduction - motivation of current study}

Design of foundation for bridge structures requires accurate research of soil subgrade, hence a wide range of geotechnical investigations. They include both laboratory studies and field testing as well; however other respective data can be also used and interpreted for the limit state under consideration. It is important to reach high level of knowledge and geotechnical certainty to allow safe designing the bridge foundation so as to ensure proper possible displacement, rotation and stability of foundations at most unfavourable conditions [1]. The scope of testing to be done depends on geotechnical category of a given object, the bridge abutments and piers are classified into the second geotechnical category. The ordinance [2] specifies that the following determinations should be carried out for the objects of the second geotechnical category:

- type of soil,

- physical and mechanical features of the soil, such as: internal friction angle, cohesion, undrained shear strength, modulus of compressibility or deformation.

The methods to be used for these testing include:

\footnotetext{
* Corresponding author:225219@student.pwr.edu.p1
} 
- static and dynamic probing,

- pressuremeter test (PMT) and dilatometer test (DMT),

- testing with cross - tip probe and soil load tests.

What need to be stressed, bridge construction subject to special requirements for displacements (settlements) as the damages to the whole structure resulting from these phenomena are not acceptable. Of special importance are the bridge abutments which connect with road; no settlement or resulting surface irregularities are acceptable [3]. While carrying out expertise or during monitoring the displacements of a given bridge, it can be noted, for example, non - uniform settlement of supports which reveal themselves as barrier bending or tightening the expansion joints. The reasons are, among others, poor or incomplete testing of soil subgrade or failure to observe proper sequence of works [4].

Therefore, geotechnical testing plays important role in design process; so it should be complete to determine both the limit state of foundation bearing capacity and the limit state of serviceability. However, it is possible to run current control of soil parameters during construction works. The paper presents the way of verifying the soil deformation modulus on the basis of static plate load test (SPLT) which was then used to calculate the pile group settlement for Żernicki Bridge in Wrocław.

\section{Methods of ground modulus evaluation}

\subsection{Laboratory studies}

A basic instrument to test the stress - displacement relationship in soil is the triaxial compression apparatus. Testing consists in exerting vertical and horizontal stress on cylindrical sample placed in rubber membrane until shearing the sample. Applied stresses and changes of sample height are measured be a sensor placed outside the chamber. In this way, it is possible to determine the stress-displacement relation and then, to evaluate the displacement modulus. This is the ratio of stress rise to increase of displacement induced by this increase. Detailed procedure and considering the sample preparation are specified in Eurocode 7, Part II [5]. Testing the soil compressibility allows to estimate soil settlement which is composed of three elements: immediate settlement, settlement caused by primary soil consolidation, and secondary soil consolidation, hence the testing allows to determine both primary and secondary compressibility moduli [6]. According to the standard [7], the modulus of primary $\left(M_{0}\right)$ or secondary $(\mathrm{M})$ compressibility is defined as:

$$
M, M_{0}=\frac{\Delta \sigma}{\varepsilon}
$$

where: $\Delta \sigma_{\mathrm{i}}$-increase of stresses $(\mathrm{kPa}, \mathrm{MPa}), \varepsilon$ - sample relative displacement

\subsection{Field testing - static probing CPTU}

Laboratory studies are often related to disturbance of soil structure. Hence, more and more often soil parameters are evaluated by static probing which does not disturb soil structure, and data of cone resistance allow determining the soil profile. CPTU probing enable also, by means of empirical relationships, to determine the soil deformation modulus. Measurement with CPTU cone provides four values: $q_{c}$ - drive in resistance on the cone, $f_{s}$ - friction on sleeve, $u$ - increase of pore pressure and control column deviation from vertical [8]. Eurocode 7, Part II [5] points out some correlation between edometric modulus $E_{\text {oed }}$ and drive in resistance on the cone $q_{c}$.

This correlation is given by formula: 


$$
E_{\text {oed }}=\alpha \cdot q_{c}
$$

where: $\alpha$-correlation coefficient dependent on local experience.

When theory of elasticity is used to calculate settlement, edometric modulus may be used. In case of deep foundation, like piled foundation, when this theory is assumed for calculations, effect of vertical shearing stress on circumference of pile and operation of basis as acting under influence of uniform vertical stress are, among others, taken into account in calculations. Primary assumption is that the first phase of soil is an ideal homogenous structure with elastic parameters not influenced by pile presence $[9,10]$.

\subsection{Inverse Analysis}

In many geotechnical issues, the limit loads and displacements are known from measurements, while the basic soil parameters are not fully verified. In order to determine these parameters, it is possible to use inverse analysis where the parameter optimization methods are most often used. Unknown properties of the material constitutive model are there corrected until calculated displacements or forces are consistent with measurements. The ways of using inverse analysis are well known, e.g. for thee - axial laboratory tests, deformations around deep excavation, or data from seismic shifts [11].

This way of verification can be used for soil deformation modulus. Long - year experience and observations show that there is some difference between moduli which were obtained from test loads and from laboratory studies. This results from failure to take into account some elusive effect of soil structure disturbance while taking sample in situ and laboratory. In addition, the distribution of strains in samples is different than this in subgrade, and the hydraulic gradients are other than those occurred in nature, and other are for example in the edometer. Therefore, the values of modulus determined in laboratory differ from those from test loads by several times which was already considered in 1976 in Wilun's publications. Considerations were made to use correction coefficients for determining the values of soil modulus [12].

\section{Settlement model for single pile and group of piles}

In case a piled foundation is designed, the Eurocode 7, Part I requires to run settlement analysis both for single pile and the whole group of piles. However, it is quite difficult to evaluate the pile foundation displacements precisely, and Eurocode 7, Part I recommends taking into account uncertainties resulting from calculation model and from determination of proper soil parameters. These factors cause that displacements of piles are just approximate evaluation of displacements of the whole pile foundation. Evaluation of displacements (settlements) of pile foundations is affected, among others, by the following: geotechnical conditions of soil substrate, piling technology, layout of pile group in plan, distances between piles, stiffness of foundation structure in relation to flexible pile supports, and type of load [13].

Among the method for calculating and estimating the settlement of single pile, the following methods, among others, can be distinguished: the "load - transfer" methods which use the relation between pile resistance and soil movement around the pile; methods based on elasticity theory using Mindlin equation; and also numerical method using currently in such programmes as "Pile" (GEO 5) or Plaxis 3D Foundation [14]. In case of pile groups, there are several methods including: methods of settlement coefficient, a method of alternative foundation, analytic methods worked out on the basis of theoretical solutions where pile - soil - pile cooperation is analyse, e.g. numerical methods. 
Both in case of single pile and pile group settlement, the result of settlement analysis is the load - settlement relationship ( $\mathrm{Q}-\mathrm{s}$ ). For a single pile, it is comparison affected by some error shown as " $\sigma_{s}$ " in Fig.1. The diagram illustrates that the position of the point $\left(Q_{n}, S_{c}\right)$, can be either over or below the settlement curve $[15,16]$. Methods used for pile group calculations are more complex. It is shown, among others, in the characteristic ( $\mathrm{Q}-$ s) of the "i" pile in the group in Fig. 2 [17].

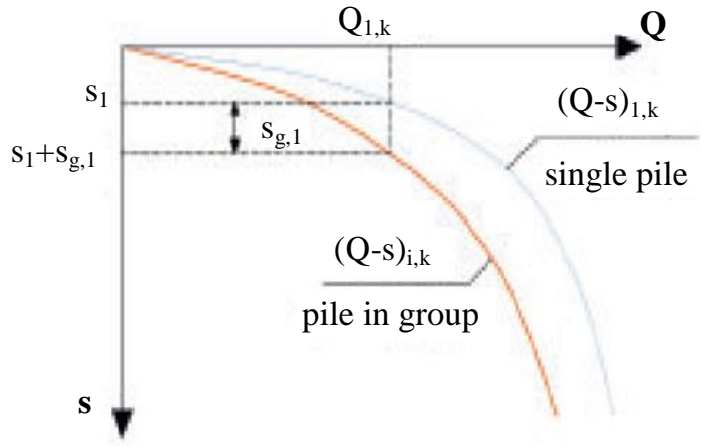

Fig. 1. Settlement curve of single pile [17]

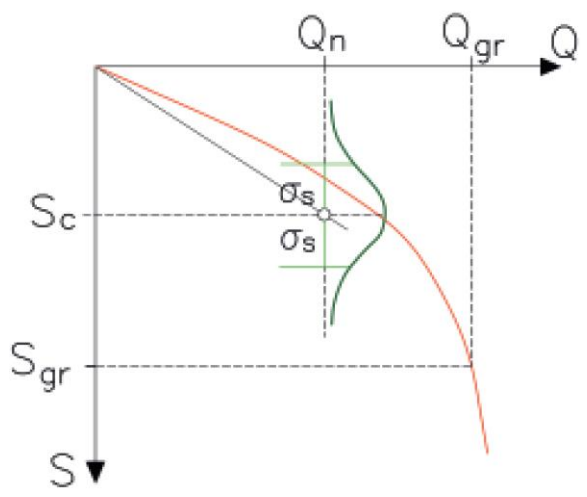

Fig. 2. Schematic diagram for determining the $\mathrm{Q}-\mathrm{s}$ characteristic of ,il" pile within a group [17]

The pile - soil - pile contact affects the settlement value both for single pile and a pile group. Attempt can be made to analyse it using simplified approach to non - linear diagram of pile settlement. A hyperbolic model, which serves to find the relation between soil - pile contact friction and relative displacement of the pile, appears to be useful for this purpose. It analyses these changes both at the beginning and the end of pile [18].

\section{Computing of ground modulus on the basis of Static Load Test results}

\subsection{Static Load Test for large diameter piles}

The analysis refers to large diameter piles applied as foundations of Żernicki Bridge abutment in Wrocław. The piles were $12.0 \mathrm{~m}$ long and $1.20 \mathrm{~m}$ in diameter made as bored piles. Their base was terminated in a load bearing silty clay which degree of plasticity was determined as rigid-flexible with cohesion $c_{u}=54.20 \mathrm{kPa}$, internal friction angle $\phi_{u}=6.9^{\circ}$, edometric primary compressibility modulus $M_{0}=35.40 \mathrm{MPa}$, edometric secondary compressibility modulus $M=44.30 \mathrm{MPa}$, and primary deformation modulus $E_{0}=20.00 \mathrm{MPa}$.

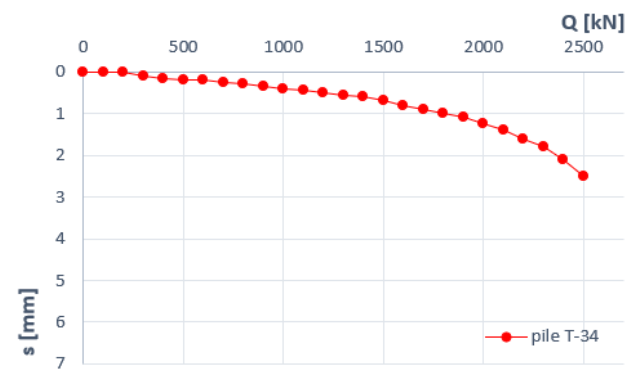

Fig. 3. Data from static load test of large diameter pile (T-34)

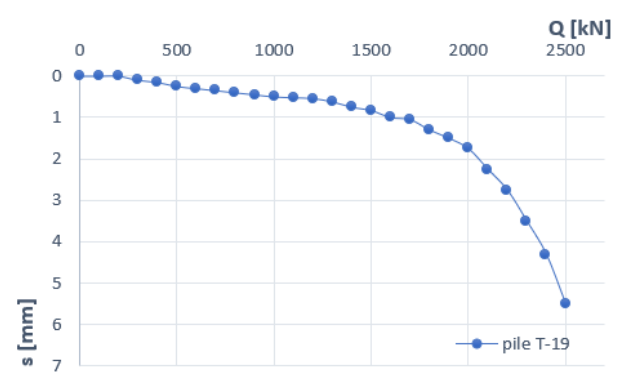

Fig. 4. Data from static load test of large diameter pile $(\mathrm{T}-19)$ 
To verify proper execution of piles and the value of settlements, which must be small for bridge structures, static test load (SLT) was made on completed piles 30 days after the piles were formed in the ground. As the adjacent piles could be used for anchoring, an anchored testing stand was designed. Following termination of test load, the load-settlement diagrams $(\mathrm{Q}-\mathrm{s})$ were drawn for two piles $(\mathrm{T}-34$ and $\mathrm{T}-19)$ which were used to run inverse analysis (Figures. 3 and 4). The range of analysed settlement was within the load limits up to $2500 \mathrm{kN}$, i.e. until the pile was released.

\subsection{Modelling the pile in GEO 5 "Pile" Programme}

Having the results from static load test, the pile was modelled in the GEO 5 „Pile" programme considering its length and diameter. Ground parameters were assumed according to geology engineering report. The pile was loaded with the force of $3120 \mathrm{kN}$, i.e. exactly what was determined as the maximum vertical force to be carried by the pile, and which is estimated as limit capacity of the pile.

Modelling a single pile in GEO 5 „Pile” programme is aimed at verifying and comparing the results obtained from the programme with those from in situ test. While controlling the results, one can found that the results for limit settlement of the pile are not compatible each other. During static load test (SPLT) the settlement for limit value (of $3120 \mathrm{kN}$ ) was $5.45 \mathrm{~mm}$ for $\mathrm{T}-34$ pile and $16.78 \mathrm{~mm}$ for $\mathrm{T}-19$ pile. Calculations in the programme were made with elastic calculation method and the value found for the maximum settlement was $25 \mathrm{~mm}$ (Figure 5). Using the elastic calculation method in GEO 5 ,Pile” programme, analysis can be made of shearing on pile shaft (Figure 6). It stems from this diagram that pile - ground - pile contact, which is one of the factors affecting settlement when designing the whole pile group, need to be taken into account. The shear value on pile side surface increases along the depth, hence the zones of pile stress zones are the spot where the highest forces accumulate, where the range includes also the pile base.

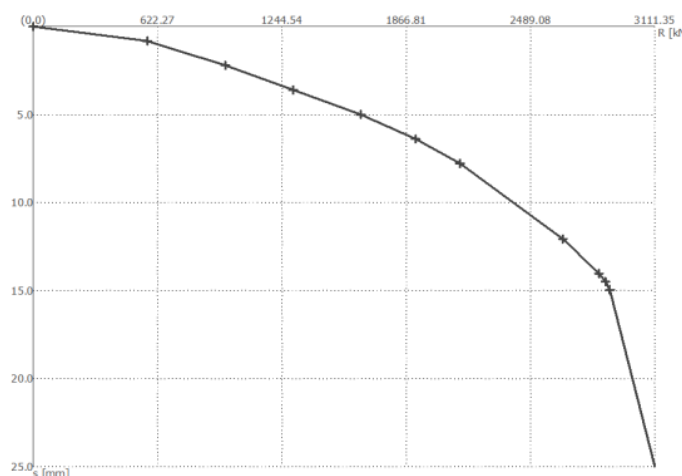

Fig. 5. Limit load curve from GEO 5 Pile Programme

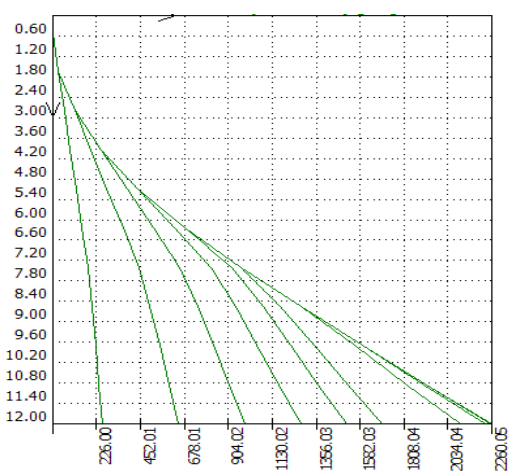

Fig. 6. Diagram of shearing on pile shaft from GEO 5 Pile Programme

\subsection{Settlement of a single pile according to Polish standard PN-83/B-02482}

The standard PN - 83/B - 02482 on pile capacity and piled foundations provide formula for calculating the settlement of a single pile:

$$
s=\frac{Q_{n}}{h \cdot E_{0}} I_{w}
$$

where:

$Q_{n}$ - pile load acting along its axis, $I_{w}$ - settlement effect coefficient, $h$ - total length of pile $E_{0}-$ ground deformation modulus, assumed in section 4.6 of the standard PN-83/B-02482 
It should be borne in mind that the coefficient $I_{w}$ is dependent, among others, from: pile stiffness coefficient, pile length - to - diameter ration, and from coefficient of non deformable layer below pile base. It is the way of pile settlement according to the Coulomb - Mohr model where ground parameter need to be defined, i.e. deformation modulus, Poisson coefficient, internal friction angle and coherence [19]. The deformation modulus $E_{o}$ is assumed in this formula. This modulus, according to the above standard, is determined from in situ testing the pile load and from respective formulae. Such determined value is used to calculate the settlement of pile group.

\subsection{Inverse analysis for Żernicki Bridge in Wrocław}

The results from static load test for large diameter piles and the formula for settlement of a single pile were used to run the inverse analysis. The deformation modulus can be found after transforming and introducing the data:

$$
E_{0}=\frac{Q_{n} \cdot I_{w}}{h \cdot s}
$$

The procedure consisted in introducing data and calculating the ground deformation modulus, each time taking into account the increase of load and also increasing pile settlement. The assumption which necessary for this procedure, and which was made at the very beginning, was that the ground modulus is $E_{0}=20.00 \mathrm{MPa}$. This value was taken from geological documentation and allowed for determining the settlement effect coefficient. The load range was $0-2500 \mathrm{kN}$ and the change of the value was $100 \mathrm{kN}$. It was observed that $E_{0}$ is higher for smaller load, hence for the less settlement, and it also decreases along with higher load as shown by the relationship $E_{0}-s$ in Figure 7.
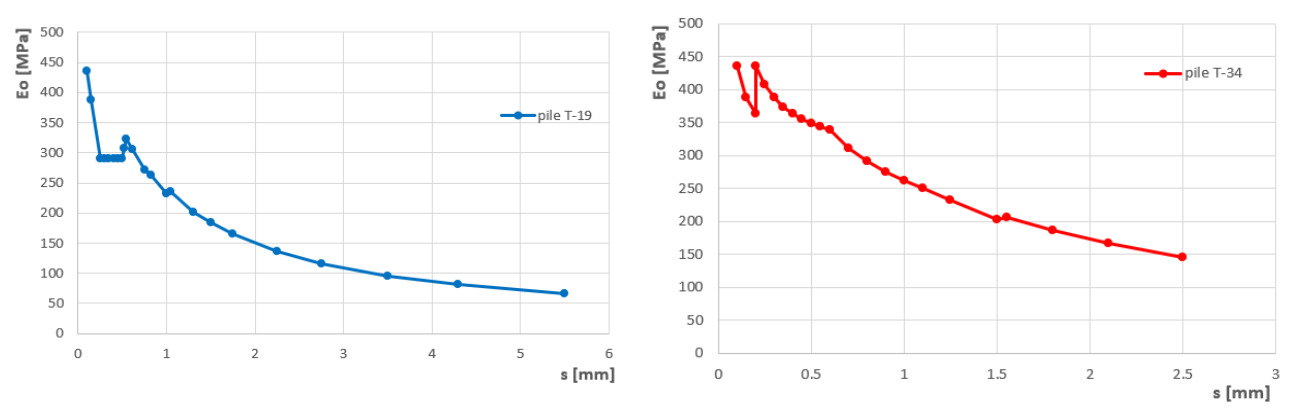

Fig. 7. Deformation modulus-settlement relationship for piles $\mathrm{T}-19$ and $\mathrm{T}-34$

The results from the procedure for two piles $(\mathrm{T}-19$ and $\mathrm{T}-34)$ were averaged. The result for one pile was $E_{0}=230.73 \mathrm{MPa}$ and for the second one, which had higher settlement, was $E_{0}=181.14 \mathrm{MPa}$. The average value for two piles was $E_{0}=205.94 \mathrm{MPa}$. A comparison was made for pile settlement value when corrected deformation modulus was used (Table 1). When collating these values, one can see that the deformation modulus affects the settlement, hence it is important to verify not only the basic ground parameters but also ground deformation modulus during geological research.

Table 1. Settlement comparison for bored piles and precast driven piles for two deformation moduli

\begin{tabular}{ccc}
\hline Pile type & $\begin{array}{c}\text { Ground deformation } \\
\text { modulus 20.0 MPa }\end{array}$ & $\begin{array}{c}\text { Ground deformation } \\
\text { modulus 205.94 MPa }\end{array}$ \\
\hline Large diameter piles $(\mathrm{D}=1.2 \mathrm{~m})$ & $11.25 \mathrm{~mm}$ & $1.17 \mathrm{~mm}$ \\
\hline Reinforced concrete driven piles $(\mathrm{D}=0.4 \mathrm{~m})$ & $5.87 \mathrm{~mm}$ & $0.85 \mathrm{~mm}$ \\
\hline
\end{tabular}




\section{Evaluation of pile group settlement - comparison with traditional approach}

Two methods are most often used to calculate settlement of pile group: the equivalent foundation method and calculation of pile group settlement according to the formula from the standard $\mathrm{PN}-83 / \mathrm{B}-02482$ (preceded by calculation of single pile settlement). The alternative foundation method consists in replacing the pile group with equivalent direct foundation (equivalent raft method) or equivalent column (equivalent pier method). Then, the settlement of equivalent foundation is calculated according to the respective method for such type of foundation [15]. These two methods were analysed for the trestle arrangement of reinforced concrete precast piles, the alternative solution for large diameter piles which were eventually used.

The following dimensions were assumed for the equivalent foundation method: $L_{F z}=12.20 \mathrm{~m}$ and $B_{F z}=9.80 \mathrm{~m}$, whereas $z_{\max }=1.5 B_{F z}=14.70 \mathrm{~m}$. The abutment load was $Q=21171.70 \mathrm{kN}$, hence the additional stress at the level of equivalent foundation was $177.20 \mathrm{kPa}$. Calculations made with equivalent foundation method, assuming the modulus $\mathrm{E}_{0}=205.94 \mathrm{MPa}$, showed the settlement of about $11.80 \mathrm{~mm}$. The standard PN $-83 / \mathrm{B}-02482$ allows, after calculating single pile settlement, to calculate pile settlement in the group:

$$
s_{i}=\sum_{j=1}^{k} s_{1 j} \cdot Q_{n j} \cdot \alpha_{i j}^{0}+s_{1 i} \cdot Q_{n i}, \text { for } j \neq i
$$

where: $s_{1}-$ single pile settlement caused by unitary load $Q_{n}=1$

$Q_{n j}$ - load for pile $j$ and pile $i$, respectively

$\alpha_{i j}^{0}$ - interaction coefficient between pile $i$ and pile $j$

The coefficient $\alpha_{i j}{ }^{\circ}$ has a major impact in calculations. In the pile group under analysis, composed of 21 precast piles, including 7 tilted at an angle of $20^{\circ}$, the value of $\alpha_{i j}{ }^{\circ}$ depended on pile position within the pile group. Outermost piles were affected by about 5 piles as the next ones were too far and did not affect on displacement of a given pile. However, piles in the middle take the highest reaction from adjacent piles. The most affected is the vertical centre pile (affected by c. 10 adjacent piles) causing its highest settlement of $3.06 \mathrm{~mm}$. This results from small distances to adjacent piles, causing the highest value of $\alpha_{i j}{ }^{\circ}$. These values are confirmed in Table 2 including values for particular areas of piles.

Table 2. Values of settlement for exemplary piles considering effect of adjacent piles

\begin{tabular}{ccc}
\hline Pipe position in assumed layout & $\sum \alpha_{F}^{0}$ & Pile settlement in group [mm] \\
\hline Outermost vertical pile & 1.18 & 1.85 \\
\hline Outermost inclined pile & 0.80 & 1.80 \\
\hline Middle vertical pile & 2.60 & 3.06 \\
\hline
\end{tabular}

\section{Modelling a group of piles in GEO5 - "Pile group" programme}

Due to differences from various calculation approaches, a pile group was modelled as an alternative solution for large diameter piles eventually used in the project. By modelling the pile group this way, the programme provided a diagram of displacements $Z$ [mm] - Figure 8. The programme also gave the result of plate displacement and rotation (Figure 9). 
This is the most awaited result when calculating bridge supports where accurate verification of support displacement is of importance to minimize it in order to protect the whole structure against settlement effects. The maximum settlement given by the programme is $6.80 \mathrm{~mm}$. It should be taken into account that the input data to the programme included edometric moduli of grounds as specified in geological engineering documents.

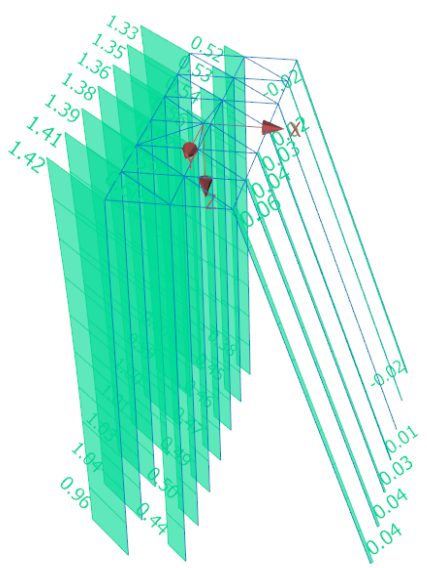

Fig. 8. Displacements Z [mm]

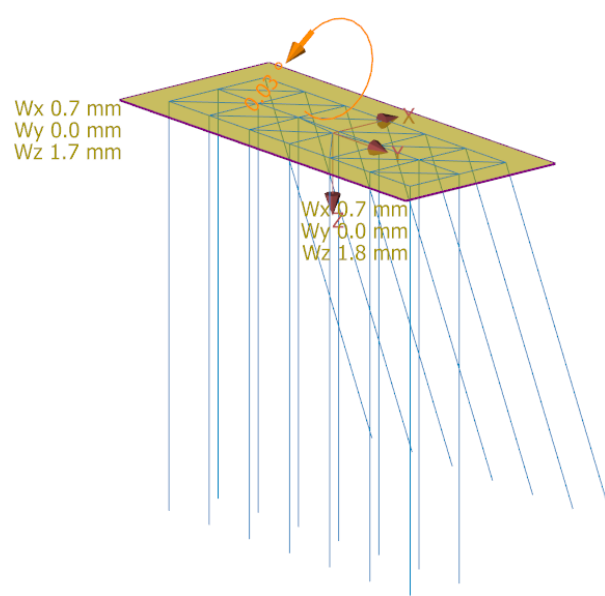

Fig. 9. Plate displacement and rotation

\section{Conclusions and final remarks}

As we can see from the example considered, various results were attained with different methods used for calculating the piled foundation settlement. Therefore, it is of importance to verify and to control the value of ground deformation modulus which affects the settlement values. The inverse analysis allows for verification the ground displacement modulus. It can find wider application as we are not always able to determine all necessary geotechnical parameters with in situ testing and laboratory studies. The data given in geological documentation not always lead to good results because they not necessarily match parameters actually existing in the subgrade. However, one can be quite dubious about application of Coulomb - Mohr model in the inverse analysis used in the paper. As the linear elasticity was assumed, estimated values of deformation modulus can be inflated as in this method the small loads cause large ground deformations. Perhaps better methods exist, like calculation model using Finite Element Method (FEM). This model was taken during designing the foundations of Rędzinski Bridge where non - linear model was used wherein the stiffness modulus was dependent on stress and deformation - this method is available in Hardening Soil model in ZSoil Programme [20]. However, in case of non linear model, there could be a problem with insufficient data, while for inverse analysis based on Coulomb - Mohr model, it is possible to get credible result in a simple way on the basis of results obtained during construction works.

The author of the paper would like to express sincere thanks to AARSLEFF Sp. z o.o. for cosponsoring of this research, Many thanks to GF - Mosty Office for provision of data from design documentation which was used to design the foundation and to run verification using inverse analysis of the ground deformation modulus. I also extend thanks to Biuro Usług Geotechnicznych "GEOTECH" for sharing data from static load tests for large diameter piles made for Żernicki Bridge in Wrocław. 


\section{References and materials consulted}

1. A. Pena, M. Valenzuela, M. Marquez, H. Pinto, Minimum geotechnical requirements for traditional and singular bridges foundations design: Chacao Suspension Bridge. Revista de la Construcción, 16 (3), pp.498-505 (2017)

2. D. Sobala, J. Rybak, Role to be played by independent geotechnical supervision in the foundation for bridge construction, IOP Conf. Ser.: Mat. Science and Eng., 245 (2), 022073, (2017)

3. J. Rybak, D. Sobala, G. Tkaczynski, Static and dynamic testing of driven piles in Poland, 8th int. conf., Lisbon, Portugal, 8-10 September 2008, Amsterdam: IOS Press, 615-618, (2008)

4. P. Rychlewski, Przemieszczenia fundamentów obiektów inżynierskich, Inżynier Budownictwa, 4, (2017)

5. EN 1997-2: Eurocode 7: Geotechnical design - Part 2: Ground investigation and testing

6. M. Bouassida, I. Said, About estimation of settlement by the oedometric and pressuremeter methods, $2^{\text {nd }}$ Int. Conf. on Geotech. Eng. October 25-27, Hammamet Tunisia, 1, 777-786, (2010)

7. M. Drusa, Improvement in evaluation of neogenous soils by CPT testing, $12^{\text {th }}$ Int. Multidisciplinary Scientific GeoConf. and EXPO - Modern Management of Mine Producing, Geology and Environmental Protection, SGEM 2012, 2, 151-158, (2012)

8. J. Vlcek, R. Bulko, L. Bartuška, J. Kmec, Soil Consolidation Parameters Derived from CPTu Probing, Procedia Engineering, 161, 180-184, (2016)

9. I. Bagińska, M. Wyjadłowski, M. Sacha, Study of the results of static CPTu test for capacity calculation of the pile. 17th Int. Multidisciplinary Scientific GeoConf., SGEM 2017, Albena, Bulgaria, 17 (12), 825-832, (2017)

10. M. Wyjadłowski, I. Bagińska, J. Rainer, Probabilistic assessment of pile capacity based on CPTu probing including random pile foundation depth, MATEC Web Conf., 196, 01058, (2018)

11. Y.M.A. Hashash, H. Song, The Integration of Numerical Modeling and Physical Measurements through Inverse Analysis in Geotechnical Engineering, KSCE Journal of Civil Engineering, 12 (3), 165-176, (2008)

12.P. Popielski, Weryfikacja parametrów podłoża na podstawie wykonanej analizy wstecznej przy realizacji głębokich posadowień w Warszawie. Archit., 12 (2), (2013)

13. EN 1997-1, Eurocode 7: Geotechical design - Part 1: General rules.

14. H.G. Poulos, E.H. Davis, Pile foundation analysis and design, Rainbrow-Bridge Book Co., (1980)

15. D. Sobala, G. Tkaczyński, Interesting Developments in Testing Methods Applied to Foundation Piles, IOP Conf. Ser.: Mat. Science and Eng., 245 (2), 022074, (2017)

16. J. Rybak, M. Król, Limitations and risk related to static capacity testing of piles "unfortunate case" studies, MATEC Web Conf., 146, 02006, (2018)

17. K. Gwizdała, A. Krasiński, Fundamenty palowe, obliczenia z zastosowaniem zasad Eurokodu 7 i doświadczeń krajowych. Acta Sci. Pol. Architektura, 15 (2), (2016)

18. Zhang Qianging, Shucai Li, Fayun Liang, Min Yang, Qian Zhang, Simplified method for settlement prediction of single pile and pile group using hyperbolic model International Journal of Civil Engineering, Geotechnique, 146-159 (2013)

19. G. Varga, Z. Czap, Soil Models: Safety factors and settlements, Periodica Polytechnica Ser. Civ. Eng. 48 (1-2), 53-63, (2004)

20. E. Dembicki, M. Cudny, A. Krasiński, K. Załęski, Pylon foundation of a cable stayed bridge at motorway ring road of Wrocław. $18^{\text {th }}$ International Conference on Soil Mechanics and Geotechnical Engineering, Paris, 4, 2715-2718, (2013) 